\title{
FORECAST RESEARCH OF DYNAMICS OF WORLD OIL PRICES BASED ON COMPLEX FRACTAL ANALYSIS
}

\section{Cheverda S.S., Maksyshko N.K.}

\author{
Zaporizhzhia National University \\ Ukraine, 69600, Zaporizhzhia, Zhukovsky str., 66 \\ cheverdaserega@gmail.com, maxishko@ukr.net \\ ORCID: 0000-0003-2161-037X, 0000-0002-0473-7195
}

\section{Key words:}

oil price, time series, complex fractal analysis, sequential RIS analysis method, fuzzy depth of memory set, forecast horizon.
The object of the article's research is the dynamics of the price of Brent oil. Relevance of the article due to the fact that in today's world oil prices are an important economic factor in the world economy in general and on the national economic systems in particular. The study has been conducted with a complex fractal analysis, the essence of which is to use a Hearst's rescaled range (RIS) analysis and methods sequential RIS-analysis, which in the case of the fractal nature of economic dynamics enables to deepen the knowledge of in conditions of instability, nonlinearity and uncertainty. As a result of the study of time series of daily world oil prices for the period from 02.01 .2013 to 16.12 .2019 as a whole and for 7 years, it has been revealed, all of them are persistent, have long-term memory and inertia property. The use of the sequential RIS analysis method allowed for fuzzy sets of time series memory depths to be constructed and a detailed retrospective analysis of the dynamics of changes in memory depth characteristics over the observation period has been made. For this purpose, such system characteristics are defined as the depth of memory that is most possible; the depth of memory that is the centre of gravity of the fuzzy set; maximum well depth of memory has been found; an indicator of information entropy of fuzzy set of depth of memory; an indicator of the redundancy of the fuzzy set of the depth of memory as a measure of "noise" in the time series, etc. As a result, the peculiarities of the dynamics of world oil prices have been revealed and their comparative analysis has been carried out in the context of years. Recommendations for determining the forecast horizon have been developed.

\section{ПЕРЕДПРОГНОЗНЕ ДОСЛІДЖЕННЯ ДИНАМІКИ СВІТОВИХ ЦІН НА НАФТУ НА БАЗІ КОМПЛЕКСНОГО ФРАКТАЛЬНОГО АНАЛІЗУ}

Чеверда С. С., Максишко Н. К.

Запорізький національний університет

Украӥна, 69600, м. Запоріжжя, вул. Жуковського, 66

\begin{abstract}
Ключові слова:
ціна на нафту, часовий ряд, комплексний фрактальний аналіз, метод послідовного $\mathrm{R} \backslash \mathrm{S}$-аналізу, нечітка множина глибини пам'яті, горизонт прогнозування.
\end{abstract}

Об'єктом дослідження статті є динаміка ціни на нафту марки Brent. Актуальність статті зумовлена тим, що світові ціни на нафту є важливим економічним фактором впливу на світову економіку загалом і на національні економічні системи зокрема. Дослідження проведено засобами комплексного фрактального аналізу, сутність якого полягає в застосуванні відомого методу нормованого розмаху Херста і методу послідовного RlSаналізу, який у випадку фрактальної природи економічної динаміки дає змогу поглибити знання щодо неї в умовах нестійкості, нелінійності й невизначеності. У результаті дослідження часових рядів щоденних світових цін на нафту за період з 02.01.2013 по 16.12.2019 загалом та в розрізі 7 років виявлено, що всі вони $є$ персистентними, мають довготривалу пам'ять та властивість інерційності. Застосування методу послідовного RIS-аналізу дало змогу побудувати нечіткі множини глибини пам'яті часових рядів та провести детальний ретроспективний аналіз динаміки змін характеристик глибини пам'яті впродовж періоду спостереження. Для цього визначено такі системні характеристики, як глибина пам'яті, що є найбільш можливою; глибина пам'яті, що є центром тяжіння нечіткої множни; максимальна глибина пам'яті; показник інформаційної ентропії нечіткої множини глибини пам'яті; показник надлишковості нечіткої множини глибини пам'яті як міра «зашумленості» ЧР та ін. У результаті виявлено особливості динаміки світових цін на нафту та проведено їх порівняльний аналіз у розрізі років. Розроблено рекомендації щодо визначення горизонту прогнозування.

\section{Statement of the problem}

In the context of globalization, world oil prices are an important economic factor influencing the global economy in general and national economic systems in particular. The perfection of the energy pricing mechanism depends, first of all, on the energy security of each country. The creation of reliable forecasts of oil prices is an important component in the development of state budgets, justification of investment projects, economic evaluation of oil reserves in the depths and more. The price of oil is one of the most important factors 
affecting global economic growth, industrial development, inflation and interest rates, food prices, poverty and other socio-economic processes.

It should be noted that oil prices have been very volatile in recent years. This volatility in oil prices causes great damage to both developing and developed countries. In particular, high oil costs affect the economy at the macro level, while temporary low prices delay the necessary investment in energy. Changing consumer prices also complicate the use of new business models energy consumption and finding their replacements. Supply and cost problems are accompanied by environmental problems, in which oil also plays a major role.

The importance of oil price forecasting has long been proven in current scientific literature, as well as in economic press and programmatic documents. The media provides unofficial data on the macroeconomic effects of recent fluctuations in world oil prices. In general, the importance of global oil price projections stems from the fact that they are necessary for stakeholders, including knowledge-intensive industries, investors, financial corporations and risk managers, as well as for central banks to measure economic stability. However, the forecasting of oil prices is complicated by the fact that their dynamics change over time as a result of the influence of various fundamental factors such as, for example, the demand or supply of oil, the volume of reserves along with others.

Therefore, awareness of the contemporary situation and make recommendations for selecting relevant methods of forecasting oil prices is important before the forecast analysis that aims to identify the characteristics of the system dynamics of prices that you can evaluate its features such as instability, nonlinearity and uncertainty.

\section{Analysis of recent studies and publications}

The problems of the global energy commodity market research and volatile oil prices are reflected in numerous publications domestic and foreign researchers, including Ya. Vytvytsky [1] O. Kratt, I. Kirnos in [2] William Nikonenko [3 ], O. Kohuta [4], O. Bandura [5], D. Kokurina and G. Melkumov [6], M. Musi [7], and also in the reviews of world organizations - OPEC (8), UNCTAD [9] , MEA (IEA) [10] and others.

Practical and theoretical issues of energy price analysis and forecasting have been considered, in particular, in the works of such scientists as A. Prahovnik, Y. Rudenko, B. Stogni and , G. Pivnyak , I. Karp [11], V. Bushuyev, A. Konoplyanyk , J. Mirkin [12] and other authors. Substantial works in the field of technical analysis belong to Western researchers, in particular, R. Colby [13], A. Elder [14] and others.

In [15] the authors of this article analyse the dynamics of world prices for oil and natural gas for the period from January 1986 to May 2010. With an applying statistical methods and methods of complex fractal analysis enabled to make it possible to confirm hypothesis of nonlinearity price dynamics for oil, its fractal nature, and also obtained some characteristics of the depth of memory inherent in it, and to conduct a comparative analysis of the predictability of the relevant prices. In [16] the author suggested systematization characteristics economic dynamics in conditions of instability, nonlinearity and uncertainty in the form of quantitative assessment based on figures obtained from the use of complex fractal analysis. On maintenance of complex fractal analysis involves the use of a known method of normalized swing Hurst (traditional R\S-analysis) [17] and method consistent R $\backslash S$-analysis [18], which in the case of the fractal nature of economic dynamics enables to deepen the knowledge about it in terms of instability, nonlinearity and uncertainty.

However, a thorough retrospective analysis of the dynamics of oil prices over the past decade has not been conducted.

\section{Objectives of the article}

The purpose of the work is before the forecast is the study of the dynamics of world prices for crude oil Brent using tools of complex fractal analysis to determine its characteristics and developing recommendations to determine the horizon forecasting.

\section{The main material of the research}

The object of the study is time series (TS) $G$ that daily world prices for crude oil Brent for the period 02.01.2013 to 12.16.2019 [19] (Fig. 1).

To detect possible changes in the character dynamics during the period under review, the experiments and the dynamics of prices in each year separately, that is, consider splitting TS $G$ into parts, $G=\bigcup_{2013}^{2019} G_{i}$, where $G_{i}$ - the value of world Brent oil prices over the year $i, \quad i=\overline{2013,2019}$.

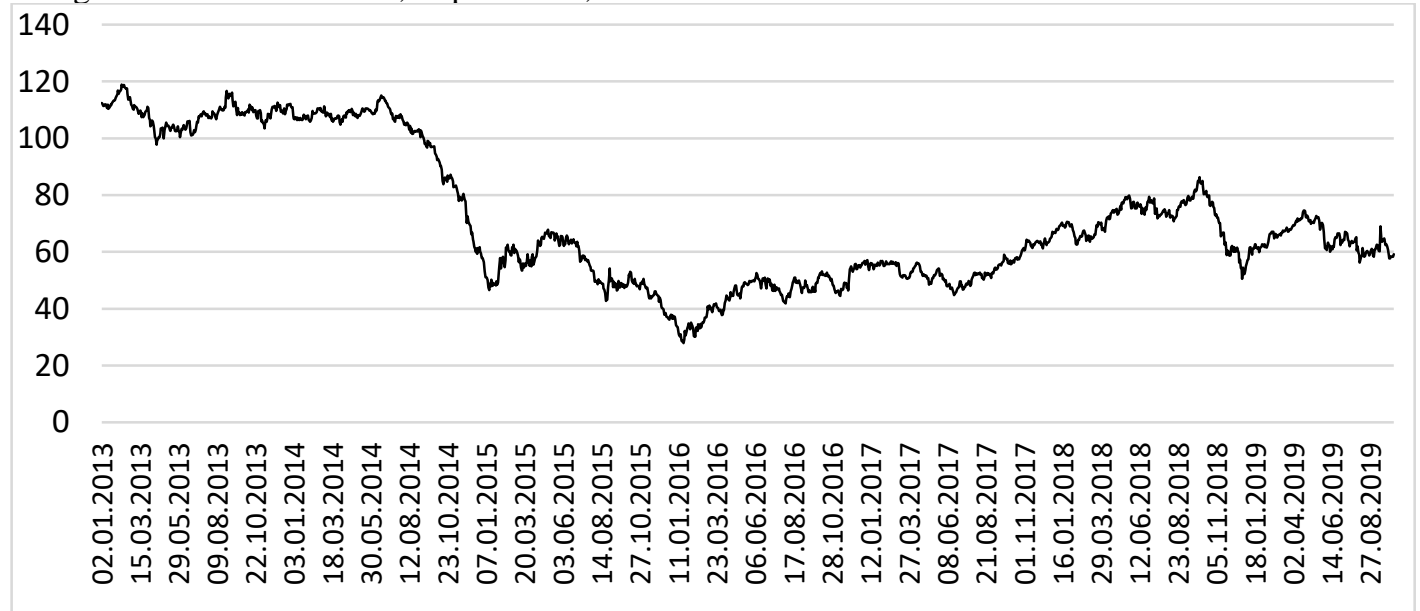

Fig. 1. The dynamics of quotations for Brent crude in the period from 02.01.2013 to 16.12.2019 (TS G) 
Considering the results of the study [15], we will consider TS $G$ and $G_{i}, i=\overline{2013,2019}$, as such, which have a fractal structure and are characterized by long-term memory [17, 18]. This is ensured by Hearst's rescaled range (R\S) analysis, which, together with the mixing procedure, is the content of the first stage of complex fractal analysis (table 1).

Table 1 - Value index Hearst for TS $G$ and $G_{i}, i=\overline{2013,2019}$ oil prices

\begin{tabular}{|c|c|c|c|c|c|c|c|c|}
\hline \multirow{2}{*}{ Hearst indicator } & \multicolumn{7}{|c|}{ Time series of oil prices } \\
\cline { 2 - 10 } & $G$ & $G_{2013}$ & $G_{2014}$ & $G_{2015}$ & $G_{2016}$ & $G_{2017}$ & $G_{2018}$ & $G_{2019}$ \\
\hline$H$ & 0,9230 & 0,9311 & 0,8694 & 0,9269 & 0,9382 & 0,8942 & 0,8706 & 0,8824 \\
\hline $\begin{array}{c}H \\
\text { after mixing }\end{array}$ & 0,6114 & 0,6238 & 0,6263 & 0,6197 & 0,6220 & 0,6004 & 0,6394 & 0,6094 \\
\hline
\end{tabular}

Belonging values of $\mathrm{b}$ index Hearst $H$ to the interval $[0,8694 ; 0,9382]$ together with the values of this indicator after conducting the test for the mixing of the levels of the time series $\left(H_{\text {mix }} \in[0,6004 ; 0,6394]\right.$ - indicates an irregularity) allows to state that the time series of the oil prices being investigated are persistent and have long-term memory

The second stage of complex fractal analysis makes it possible to obtain quantitative characteristics of the TS memory depth by applying the method of sequential $R \backslash S$ analysis [18]. Recall that with units this method is to build a family of $S(G)$ time series of offset for the start of the time series and applying iterative procedure analysis of relevant each time along with the family of $\mathrm{S}(G) \quad H$ trajectory and $R \backslash S$-trajectory the purpose determining the "breakpoint" of the corresponding R $\backslash \mathrm{S}$-trajectory from the trend. This "breakpoint" signals the loss of TS the beginning of the TS, and the number 1 of the corresponding TS level can be selected as a lower estimate of the depth of memory about the beginning of the TS of the family $S(G)$. We also recall [16] that the application of this method allows to take into account the changing

\section{$L(G)$}

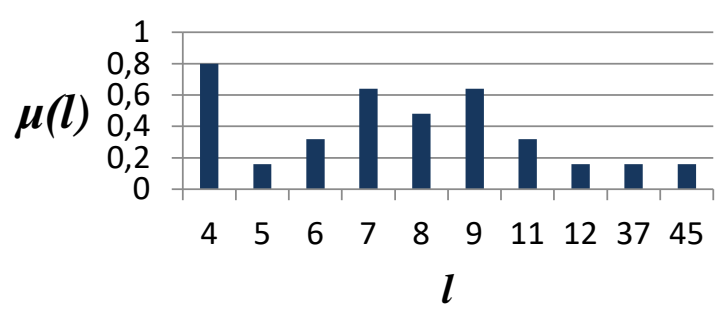

\section{$L(G 2013)$}

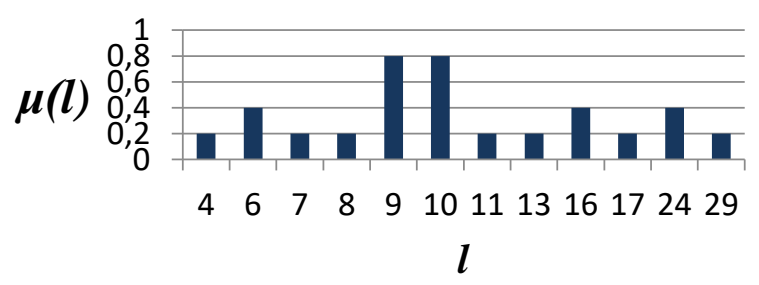

nature of price dynamics, to identify the set of cycles (quasicycles) that are characteristic of the TS under study. To assess the depth of memory for the TS $G$ in general the defined in [18] procedure formed fuzzy set $L(G)$, by pair wise combining a pair of elements $l$ elements and corresponding $\mathrm{s}$ their values $\mu(l)$ membership function, that is

$$
L(X)=\left\{(l, \mu(l)), l \in L^{0}\right\},
$$

where

$L^{0}=\operatorname{supp} L(X)=\left\{l_{i} \in N, i=1,2, \ldots .: \quad \mu_{L}\left(l_{i}\right)>0\right\}$

- fuzzy set carrier.

The estimation of the depth of memory for the whole series reflects the uncertainty generated by the external and internal effects on the dynamics being investigated.

Construct fuzzy sets memory depth for each of the considered time series $G$ and $G_{i}, \quad i=\overline{2013,2019}$ in oil prices. The results are presented in Fig. 2 and 3.

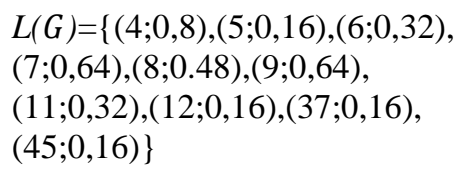

$L\left(G_{2013}\right)=\{(4 ; 0,2),(6 ; 0,4),(7 ; 0,2)$,

$(8 ; 0,2),(9 ; 0,8),(10 ; 0,8),(11 ; 0,2)$,

$(13 ; 0,2),(16 ; 0,4),(17 ; 0,2),(24 ; 0,4)$,

$(29 ; 0,2)\}$ 
$L(G$ 2014)

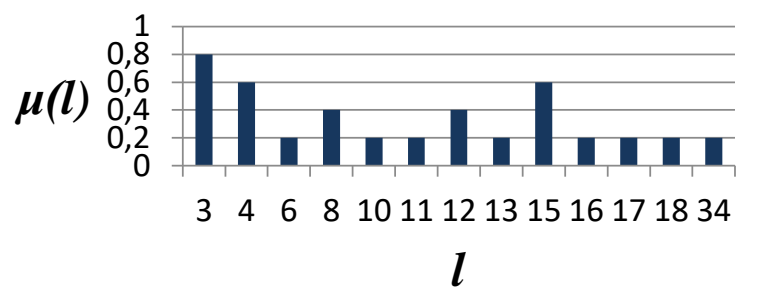

$L(G$ 2015)

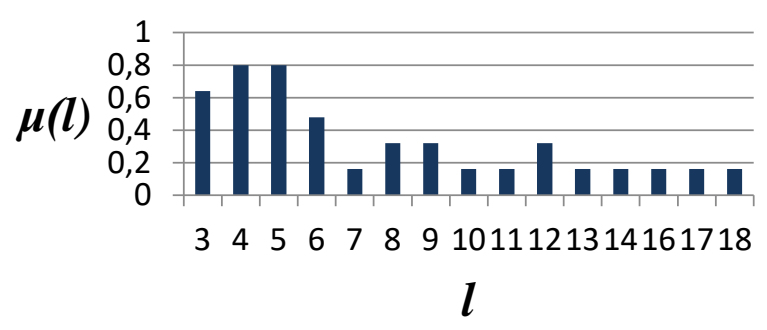

$L\left(G_{2014}\right)=\{(3 ; 0,8),(4 ; 0,6),(6 ; 0,2)$, $(8 ; 0,4),(10 ; 0,2),(11 ; 0,2),(12 ; 0,4)$, $(13 ; 0,2),(15 ; 0,6),(16 ; 0,2),(17 ; 0,2)$, $(18 ; 0,2),(34 ; 0,2)\}$
$L\left(G_{2015}\right)=\{(3 ; 0,64),(4 ; 0,8)$,

$(5 ; 0,8),(6 ; 0,48),(7 ; 0,16),(8 ; 0,32)$, $(9 ; 0,32),(10 ; 0,16),(11 ; 0,16)$, $(12 ; 0,32),(13 ; 0,16),(14 ; 0,16)$, $(16 ; 0,16),(17 ; 0,16),(18 ; 0,16)\}$.

Fig. 2. Fuzzy sets of TS memory depth $G$ and $G_{i}, i=\overline{2013,2015}$ oil prices

\section{$L(G$ 2016)}

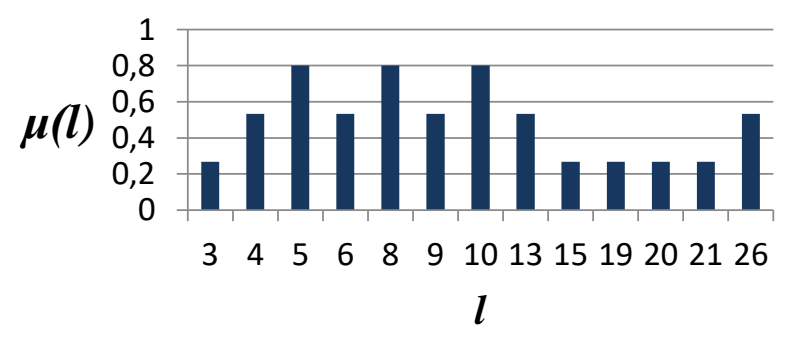

\section{$L(G 2017)$}

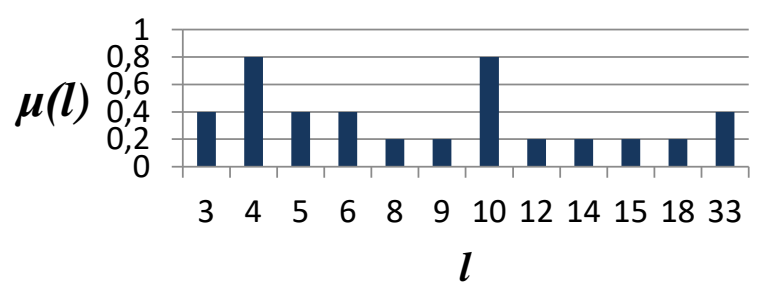

$L(G 2018)$

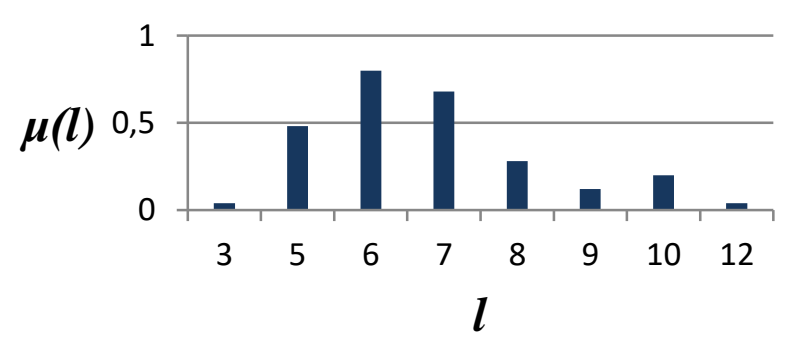

$L\left(G_{2016}\right)==\{(3 ; 0,27),(4 ; 0,53),(5 ; 0,8)$, $(6 ; 0,53),(8 ; 0,8),(9 ; 0,53)$, $(10 ; 0,8),(13 ; 0,53),(15 ; 0,27)$, $(19 ; 0,27),(20 ; 0,27),(21 ; 0,27)$, $(26 ; 0,53)\}$

$L\left(G_{2017}\right)=\{(3 ; 0,4),(4 ; 0,8),(5 ; 0,4)$, $(6 ; 0,4),(8 ; 0,2),(9 ; 0,2)(10 ; 0,8)$, $(12 ; 0,2),(14 ; 0,2),(15 ; 0,2)$, $(18 ; 0,2),(33 ; 0,4)\}$

$L\left(G_{2018}\right)=\{(1 ; 0,04),(3 ; 0,48),(4 ; 0,8)$,

$(5 ; 0,68),(6 ; 0,28),(7 ; 0,12),(8 ; 0,2)(10 ; 0,04)\}$ 


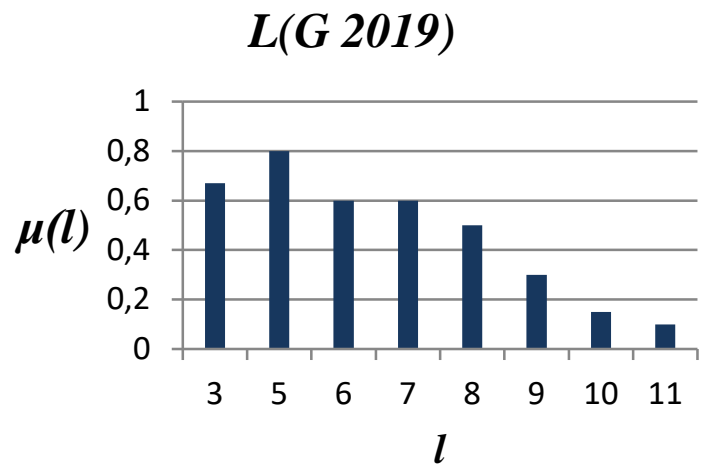

$L\left(G_{2019}\right)=\{(1 ; 0,7),(3 ; 0,8),(4 ; 0,6)$,

$(5 ; 0,6),(6 ; 0,5),(7 ; 0,3)$,

$(8 ; 0,15)(9 ; 0,1)\}$.

Fig. 3. Fuzzy sets of TS $G_{i}, i=\overline{2016,2019}$ memory depth oil prices

Comparative analysis of fuzzy s sets memory depth of each of the considered time series $G$ and $G_{i}, i=$ $\overline{2013,2019}$ oil prices allows the following conclusions:

1) behavioural characteristics TS $G$ generally can not serve as a benchmark to assess each of its segments $G_{i}, i=$ $\overline{2013,2019}$. This conclusion follows in particular from the fact that the TS $G$ is characterized uyetsya considerable volatility (value $\mu(4)=0,8$ ) in contradistinction to TS $G_{2013}$ or $G_{2018}$, for which the value $\mu(3) \vee \mu(4)$ does not exceed 0,2 .

2) during the studied period, price behaviour has changed significantly in different years: 2013 and 2018 were the most "calm" in the sense of long-term memory. Although their characteristics are also different: 2013 is trendier with a characteristic memory depth $l=9$ and $l=10$, in contradistinction to 2018 with the most characteristic memory depth $l=6$.

3 ) the particular instability differs between 2014, 2015, 2017 and 2019 (characteristic of these years is the presence of short cycles (length $l=3$ or $l=4$ ).

The dynamics of changes in the characteristics of the TS memory depth are presented in Fig. 4

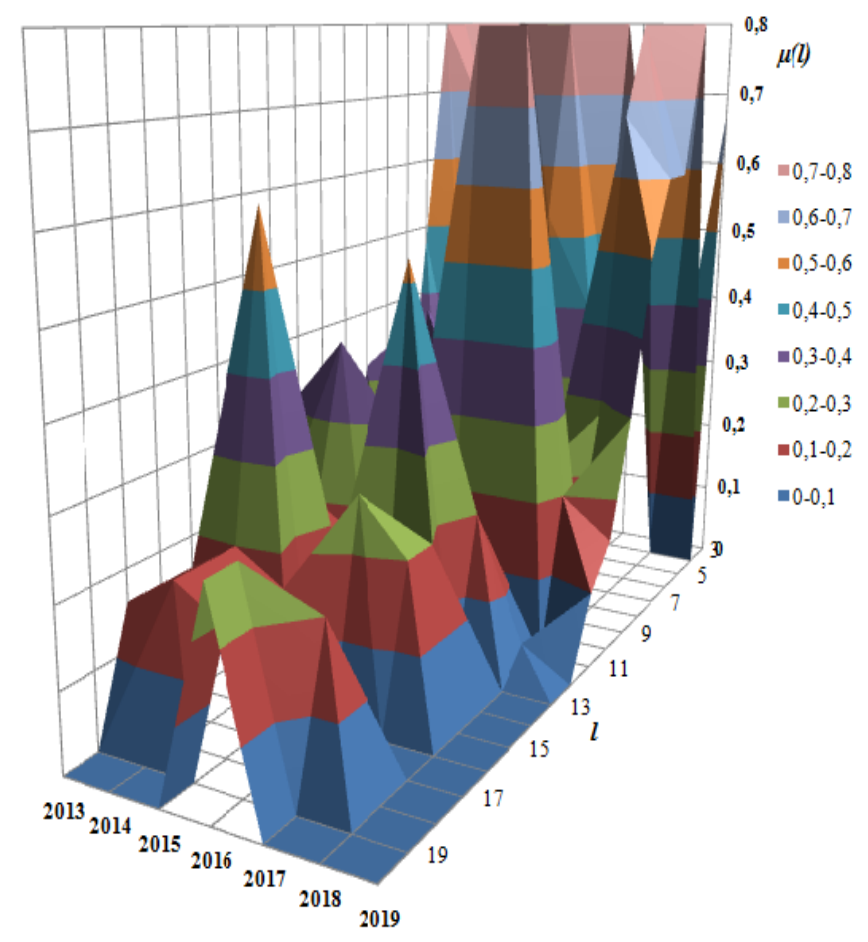

a)

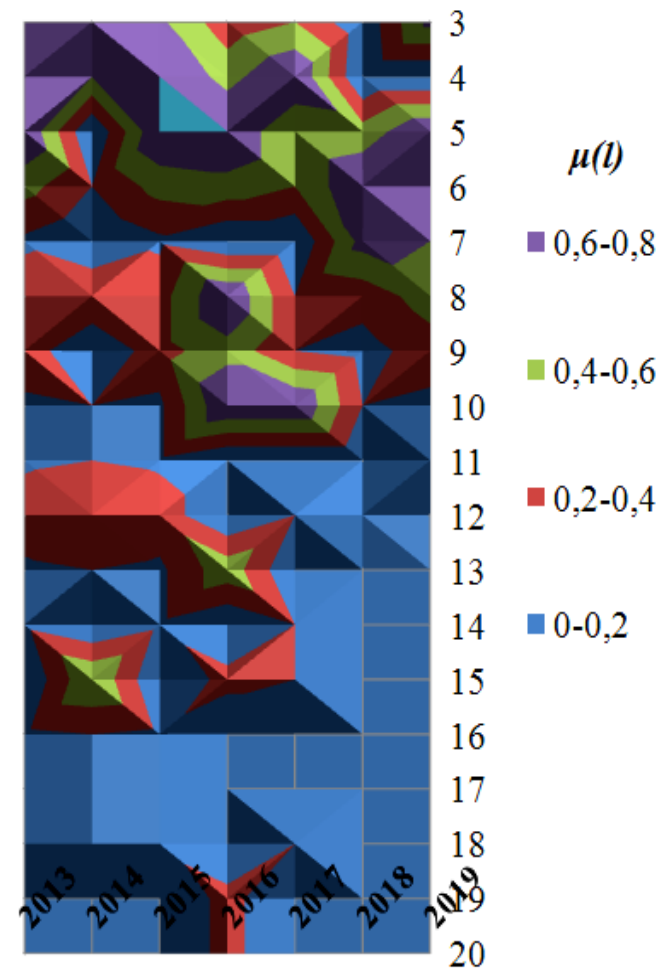

b)

Fig. 4. Dynamics of change in fuzzy sets of the depth of memory of CR oil prices over 7 years: 2013 -2019:

a) spatial dynamics; b) change map

The results of complex fractal analysis create the conditions for a more detailed analysis of the memory characteristics of the time series being analysed. We define other system characteristics [16] ST, namely: the depth of memory, which is the most possible (lH3); the depth of memory, which is the centre of gravity of the fuzzy set (ICT); maximum in depth of occurring memory (lmax); the depth of memory, which is the center of gravity of the significant (by a predefined degree of significance $\varepsilon$ ) levels for the set $(1 \varepsilon \mathrm{CT})$; the regularity of the detected pattern in terms of significance $\varepsilon$; indicator of information entropy of fuzzy set of depth of memory 
(Hentrop_L); an indicator of the information entropy of a significant part of fuzzy set of depth of memory (Heentrop_L); an indicator of the redundancy of a fuzzy set of depth of memory ( $\mathrm{SH}(\mathrm{G}))$, which can be considered as a measure "noise" of TS.
Summary results of calculations are definite indicators of estimation of system characteristics of dynamics of the TS $G$ in general and its components $G_{i}, i=\overline{2013,2019}$ are shown in Table. 2.

Table 2 - Values of oil price dynamics indicators for the period from 02.01.2013 to 16.12.2019

\begin{tabular}{|c|c|c|c|c|c|c|c|c|}
\hline \multirow{2}{*}{ Indicators } & \multicolumn{7}{|c|}{ The price of oil } \\
\cline { 2 - 10 } & $G$ & $G_{2013}$ & $G_{2014}$ & $G_{2015}$ & $G_{2016}$ & $G_{2017}$ & $G_{2018}$ & $G_{2019}$ \\
\hline$l_{H 3}$ & 4 & 9,10 & 3 & 5 & $5,8,10$ & 4,10 & 6 & 5 \\
\hline$l_{C T}$ & 10 & 12 & 11 & 8 & 11 & 10 & 5 & 5 \\
\hline$l_{\max }$ & 45 & 29 & 34 & 18 & 26 & 33 & 10 & 10 \\
\hline$\varepsilon$ & 0,4 & 0,4 & 0,3 & 0,3 & 0,5 & 0,4 & 0,3 & 0,3 \\
\hline$l_{C T}^{\varepsilon}$ & 7 & 12 & 8 & 6 & 10 & 9 & 5 & 5 \\
\hline $\begin{array}{c}\tau_{\varepsilon}(G), \\
\text { the degree of } \\
\text { typicality }\end{array}$ & 0,83 & 0,67 & 0,64 & 0,74 & 0,79 & 0,73 & 0.97 & 0.98 \\
\hline$H_{\text {entrop_L }}$ & 0,8668 & 1,6056 & 1,7743 & 1,9192 & 1,7209 & 1,6249 & 0,8584 & 0,9498 \\
\hline$H_{\text {entrop_L }}$ & 0,4253 & 0,6304 & 0,6598 & 0,7515 & 0,9573 & 0,789 & 0,7469 & 0,7720 \\
\hline $\begin{array}{c}S H \\
\text { High }(G)\end{array}$ & 0,5092 & 0,6073 & 0,6281 & 0,6084 & 0,4434 & 0,5144 & 0,4373 & 0,7071 \\
Legree of noise & Average & Low & Low & Low & Average & Average & Average \\
\hline
\end{tabular}

The analysis of the results of the study of the characteristics of fuzzy sets $L(G)$ and $L\left(G_{i}\right)$ time series memory depths $G$ та $G_{i}, i=\overline{2013,2019}$, oil prices make it possible to reach the following conclusions:

a) slight variability except TS $G$ demonstrate TS $G_{2014}$, $G_{2015}$ та $G_{2017}$ : for their dy ing characteristic and are, on the one hand, the presence of predominantly short ( $l=$ $3, l=4 \wedge l=5$ ) cycles (quasicycles), on the other hand, there is a significant discrepancy between the most commonly found memory depths $\left(l_{H 3}\right)$ and centres of gravity of the plural $L\left(G_{i}\right)$ - values $l_{C T}$ and $l_{C T}^{\varepsilon}$ (significant). ). This range of possible values of depth is quite wide (the values $l$ max ) and the greatest uncertainty behaviour (on a variety of behaviours) by the information entropy of a fuzzy set of memory depths $\left(H_{\text {entop_L }}\right)$ a number of dynamics turned out for TS $G_{2015}$ $\left(H_{\text {entop_L }}=1,9192\right)$. Restricting a fuzzy set of memory depths only to significant levels leads to a sharp reduction in uncertainty, but the presence of short cycles significantly affects the overall estimate;

b) relatively stable inertial (quiet) dynamics is characteristic of TS $G_{2013}$ and $G_{2016}$ : the length of quasicycles is determined by the indices $l_{H 3}, l_{C T}, l_{C T}$, which either coincide or differ by one unit and acquire values from the segment $[9 ; 12]$. This length of possible trend allows this indicator to be used as an acceptable forecasting horizon of two weeks;

c) special attention is needed in the last two years - TS $G_{2018}$ and $G_{2019}$. For the dynamics of the price of oil in these years are characterized by a relatively low degree of uncertainty (entropy values $H_{\text {entrop_L } L}$ and $H^{\varepsilon}$ entrop_L), a high degree of typicality $\tau_{\varepsilon}(G)$, compared to a wide range of values for possible lengths of quasicycles $\left(l_{\max }=10\right)$. In this case $l_{H 3}, l_{C T}, l_{C T}^{\varepsilon}$ coincide (or almost coincide), but acquire the value of $l=5$. This means that during the last two years, the oil market has been volatile and price inertia has taken place over the course of a week, which is likely to end with a change in trend (price spike) and then a week's inertia again.

\section{Conclusions}

The before forecast research of the dynamics of the dynamics of world oil prices of the Brent brand using the tools of complex fractal analysis revealed the peculiarity of it and which are as follows:

a) all-time series of oil prices ( $G$ and $G_{i}, i=\overline{2013,2019}$ ), what is investigated is inherent in the trend or inertia property. This means that over a period of time, it is likely that the series will preserve the acquired direction of motion, and this property should be taken into account when selecting the prediction method;

b) the time during which the price has the property to keep the acquired direction of movement is not constant. It changes under the influence of certain (fundamental and other) significant factors. This effect is reflected in the change in the depth-of-memory characteristics of the time series. Therefore, when determining the parameters of a method of predicting intended at it for long-term time series, it is advisable to have the results of monitoring to modify the characteristics of the dynamics that are typical of the period immediately preceding prediction. Thus, for the purpose of forecasting the price of oil of the Brent brand since the beginning of 2020, there is no sense in constructing a day forecast for a period exceeding 5 periods. If you increase the forecast horizon with such a value, there is a high probability of a significant increase in the forecast error.

Prospects for further research toward a perfection before the forecast analysis of the dynamics of world prices for crude oil Brent, in our opinion, is the attraction phase analysis tools for quantitative evaluation of the oscillation amplitude $b$ of prices within the identified available quasicycles and research centres trajectory of quasicycles. It is reasonable and exploration towards identifying the impact of fundamental factors to change the characteristics and dynamics of prices on oil. 


\section{References}

1. Vytvytskyi, Ya.S. (2015). Volatylnist svitovykh tsin na naftu [Volatility of world oil prices]. Naftohazova haluz Ukrainy - Oil and gas industry of Ukraine, 5, 16-20 [in Ukrainian].

2. Kratt, O.A., Kirnos, I.O. (2009). Svitovyi rynok nafty: vybir instrumentariiu piznannia [World Oil Market: the Choice of Cognition Tools] Naukovi pratsi Donetskoho natsionalnoho tekhnichnoho universytetu. Seriia: ekonomichna - Science and technology of Donetsk National Technical University. Seriya: economical, 37-2, 8993. Donetsk: DonNTU. [in Ukrainian].

3. Nikonenko, U.M. (2012). Faktory vplyvu na formuvannia tsin syrovynnykh resursiv [Factors of influence on commodity resource pricing]. Naukovi zapysky - Proceedings, 3(40), 40-46 [in Ukrainian].

4. Kohut, O.I. (2012). Tendentsii rozvytku svitovoho rynku nafty v period pislia kryzy 2008 roku [Trends in the development of the world oil market in the aftermath of the 2008 crisis]. Naukovyi visnyk NLTU Ukrainy Scientific Bulletin of NLTU of Ukraine, 22(3), 229-233 [in Ukrainian].

5. Bandura, O.V. (2018). Prohnozuvannia trendu svitovykh tsin na naftu na bazi SMI-modeli ekonomichnykh tsykliv [Forecasting the trend of light prices for naphtha on the basis of CMI-models of economic cycles]. Ekonomika i prohnozuvannia - Economy and forecasting, 2, 91-110. [in Ukrainian].

6. Kokurin, D. \& Melkumov, D. (2003). Uchastniki mirovogo rynka nefti [Participants in the global oil market]. Voprosy ekonomiki - Economic issues, 9. [in Ukrainian].

7. Michael, Mussa (2012). World Recession and Recovery: A V or an L? Peterson Institute for International Economic. pp. 106-123.

8. Organization of the Petroleum Exporting Countries (OPEC). URL: https://www.opec.org/opec_web/en/publications/338.htm.

9. United Nations Conference on Trade and Development (UNCTAD) URL: https://unctad.org/en/Pages/publications.aspx.

10. International Energy Agency (IEA) URL: https://www.iea.org/programmes/energy-efficiency-in-emergingeconomies.

11. Bondarenko, V.I., Karp, I. M., Landau, YU. O., \& Sihal, I. YA. (2013). Enerhetyka: istoriya, suchasnist' i maybutnye. Vid vohnyu ta vody do elektryky [Energy: history, present and future. From Fire and Water to Electricity]. Kyyiv [in Ukrainian].

12. Bushuev, V.V., Konoplyanik, A.A., \& Mirkin, Ya.M. (2013). Ceny na neft: analiz, tendencii, prognoz [Oil prices: analysis, trends, forecast]. Moskva: ID «Energiya» [in Russian].

13. Kolbi, R. (2009). E`ncziklopediya tekhnicheskikh indikatorov ry`nka [Encyclopedia of technical market indicators]. Moskva: Al pina Pablisherz [in Russian].

14. E`lder, A. (2010) Kak igrat` i vy`igry`vat`na birzhe: Psikhologiya. Tekhnicheskij analiz. Kontrol`nad kapitalom [How to play and win on the stock exchange: Psychology. Technical analysis. Capital control]. Moskva: Al pina Pablisherz [in Russian].

15. Maksyshko, N.K., \& Cheverda, S.S. (2010). Analiz prohnozovanosti dynamiky svitovykh tsin na naftu ta pryrodnyi haz [Analysis of predictability of world oil and natural gas price dynamics]. Visnyk Zaporizkoho natsionalnoho universytetu. Ekonomichni nauky - Bulletin of Zaporizhzhia National University. Economic sciences, 2(6), 122-129 [in Ukrainian].

16. Maksyshko, N.K. (2010). Otsiniuvannia systemnykh kharakterystyk ekonomichnoi dynamiky na bazi rezultativ kompleksnoho fraktalnoho analizu [Estimation of systemic characteristics of economic dynamics on the basis of the results of a comprehensive fractal analysis]. Visnyk Zaporizkoho natsionalnoho universytetu. Ekonomichni nauky - Bulletin of Zaporizhzhia National University. Economic sciences, 2(10), 119-129 [in Ukrainian].

17. Peters, E. (2000). Khaos i poryadok na rynkakh kapitala. Novyy analiticheskiy vzglyad na tsikly, tseny i izmenchivost rynka [Chaos and order in capital markets. A new analytical look at cycles, prices and market volatility]. Moskva: Mir [in Russian].

18. Maksyshko, N.K. (2009). Modelyuvannya ekonomiky metodamy dyskretnoyi neliniynoyi dynamiky [Modeling of economy by discrete nonlinear dynamics methods]. V.O. Perepelytsya (Ed). Zaporizhzhia: Polihraf [in Ukrainian].

19. Fiuchers na neft Brent [Brent Oil Futures [Brent Oil Futures]. investing.com. URL: https://ru.investing.com/commodities/brent-oil-historical-data. 